\title{
CERAMIC MEMBRANE ENABLING TECHNOLOGY FOR IMPROVED IGCC EFFICIENCY
}

\section{QUARTERLY TECHNICAL PROGRESS REPORT}

For Reporting Period starting October 1, 2002 and ending December 31, 2002

Praxair Program Manager: $\quad$ Ravi Prasad

DOE Program Manager: Jenny Tennant

Report Issue Date: March 2003

DOE AWARD NO. DE-FC26-99FT40437

Submitted by:

Praxair, Inc.

175 East Park Drive

Tonawanda, NY 14150 


\section{DISCLAIMER:}

This report was prepared as an account of work sponsored by an agency of the United States Government. Neither the United States Government nor any agency thereof, nor any of their employees, makes any warranty, express or implied, or assumes any legal liability or responsibility for the accuracy, completeness, or usefulness of any information, apparatus, product, or process disclosed, or represents that its use would not infringe privately owned rights. Reference herein to any specific commercial product, process, or service by trade name, trademark, manufacturer, or otherwise does not necessarily constitute or imply its endorsement, recommendation, or favoring by the United States Government or any agency thereof. The views and opinions of authors expressed herein do not necessarily state or reflect those of the United States Government or any agency thereof.

\section{ABSTRACT:}

This quarterly technical progress report will summarize work accomplished for Phase 2 Program during the quarter October to December 2002. In task 1 improvements to PSO1x have shown increased performance in strength and stability. In task 2, PSO1d and PSO1x elements have been fabricated for testing in the pilot reactor. In task 3 , the lab-scale pilot reactor has been operated for 1000 hours. In task 6 initial power recovery simulation has begun. In task 7, HYSIS models have been developed to optimize the process for a future demonstration unit. 


\section{TABLE OF CONTENTS}

A. Executive Summary Page 3

B. Experimental Methods Page 3

B.1. OTM Element Reliability Page 3

B.2. Element Fabrication Page 3

B.3. Systems Technology Page 3

B.4. Power Recovery Page 3

B.5. Process Analysis and Economics Page 3

C. Results and Discussion $\quad$ Page 4

C.1. OTM Element Reliability Page 4

C.2. Element Fabrication Page 4

C.3. Systems Technology Page 4

C.4. Power Recovery Page 4

C.5. Process Analysis and Economics Page 4

D. Conclusion $\quad$ Page 4

E. References $\quad$ Page 4

F. List of Publications Page 5

G. Appendix - Limited Rights Data Page A1 


\section{A. Executive Summary}

The objectives of the first year of phase 2 of the program are to construct and operate an engineering pilot reactor for OTM oxygen. Work to support this objective is being undertaken in the following areas in this quarter:

- Element reliability

- Element fabrication

- Systems technology

- Power recovery

- IGCC process analysis and economics

The major accomplishments this quarter were

- Methods to improve the strength and stability of PSO1x were identified.

- The 01 reactor was operated at target flux and target purity for 1000 hours.

\section{B. Experimental Methods}

\section{B.1. OTM Element Reliability Experimental Methods}

Characterization of OTM and substrate materials has been undertaken using many different experimental procedures. These include permeation, crystallographic, thermomechanical, thermochemical and electrochemical measurements. Standard equipment such as XRD, SEM, dilatometry and TGA/DSC were used. In addition oxygen permeation testers were used to measure the oxygen flux of OTM elements. The permeation test facility was described in the DOE IGCC first annual report ${ }^{1}$.

\section{B.2. Element Manufacturing Experimental Methods}

Various fabrication routes have been developed to prepare composite OTM samples. The fabrication routes used are proprietary information and included in the Appendix.

\section{B.3. Systems Technology Experimental Methods}

Details of the O-1 pilot reactor operation are proprietary information and included in the Appendix.

\section{B.4. Power Recovery Experimental Methods}

HYSIS simulations are used to model power recovery options.

\section{B.5. Process Analysis and Economics Experimental Methods}

HYSIS simulations are used to model various process options. 


\section{Results and Discussion}

\section{C.1. OTM Element Reliability Results and Discussion}

Improvements to the strength and stability of PSO1x continued. Modifications to processing and other additions haven produced a $20 \%$ increase in strength and improved tolerance to various process gases and contaminants.

\section{C.2. Element Manufacturing Results and Discussion}

High quality composite elements of PSO1d and PSO1x have been routinely prepared These elements have been used successfully in O-1 to yield target flux and purity.

\section{C.3. Systems Technology Results and Discussion}

The O-1 reactor has been operated for 1000 hours at the operating temperature and pressure, producing the target oxygen flux and purity.

\section{C.4. Power Recovery Results and Discussion}

A HYSIS model has been generated and a preliminary design established based on one of the processes considered for a future demonstration plant.

\section{C.5. Process Analysis and Economics Results and Discussion}

Two models have been developed for a future demonstration plant to begin optimization of heat integration and power recovery.

\section{Conclusion}

Progress has been made in all tasks toward achieving the DOE-IGCC program objectives. In task 1, improvements to the membrane material have increased the strength and stability of PSO1x. In task 2, composite elements of PSO1d and PSO1x can be routinely prepared. In task 3, the O-1 reactor has been operated for 1000 hours. In task 6, initial power recovery work has begun. In task 7 , initial process analysis has begun to optimize heat integration and power recovery for a future demonstration plant.

\section{E. References}

[1] Prasad, Ravi, "Ceramic Membrane Enabling Technology for Improved IGCC Efficiency" 1st Annual Technical Progress Report for US DOE Award No DEFC26-99FT40437, October 2000. 


\section{F. List of Publications}

[1] "OTM - An Advanced Oxygen Technology for IGCC", Ravi Prasad, Jack Chen, Bart van Hassel, John Sirman, James White, Eric Shreiber, Joe Corpus, Joshua Harnanto, Presented at the Gasification Technologies 2002 Conference, San Franciso, October 30, 2002. 